\title{
Out of work in Argentina
}

THE letter (page 253) from more than 60 Italian scientists drawing the scientific community's attention to the situation in Argentina is a grim reminder of the difficulties surrounding university and government institutional work on a continent which for many of us in the Anglo-Saxon world is still remote and in some way unreal.

The intellectual in Argentina has never been as secure as his counterpart in West Europe and North America. Universities have been watched very closely by successive governments, and the appointments of rectors and deans have often been purely political affairs As a result there has been a steady trickle of emigrants to more secure territory-a trickle that has sometimes swelled to a flood (in 1966, for instance, 1,100 found themselves out of a job). The turnover in university staff has been accordingly immense; one academic in Britain, who has fairly strong ties with Argentina, remarked that almost every Argentinian scientist he had known had been forced, at some time, to leave. The quality of young people coming up through the major universities is, it is widely agreed, suffering as a result.

Argentina's problems in recent years have, of course, gone much deeper than instability in universities and there was genuine hope when General Videla came to power that he would be able to act against the terrorism which had led to so much indiscriminate killing. To a certain extent he has succeeded because terrorism by the left has been sat on very firmly; however, right-wing activities do not seem to have been significantly restrained. The bewildering variety of competing security organisations and the divisions within the armed forces add to the complexity of the situation. An exiled Argentinian commented that knowing how one stood in La Plata would not necessarily make one safe in Buenos Aires, and so on. It is small wonder that universities have become places of fear and that gun-carrying soldiers are in evidence.
If recent dismissals are, in general, politically directed against the left, they are not universally so; several well known right wingers have also been relieved of their posts. What seems to have happened is that the government, faced with a truly depressing economic situation requiring urgent international support, and forced to make major cuts in public expenditure, has used the opportunity to thin its ranks of those who have taken up certain political stances in the past. Those who have steered clear of politics or who openly support the Junta can survive, though in somewhat straitened circumstances.

It used to be that, with families widely spread over South America, people in trouble could move over to Chile, Uruguay or Paraguay. Indeed Uruguay was often called the Switzerland of South America. No longer; the Uruguayans in their zeal to stamp out the Tupamaro guerillas seem to have 'processed' an extraordinary large proportion of the population and to have allowed torture to become rampant. The fate of the mathematician Jose Massera who has been imprisoned since last October and has suffered some grievous injuries is likely to deter most academics from choosing to move over to Montevideo.

The pressure, then, is really on the wider community of scientists to continue to absorb where necessary or, even more, just to keep in touch-a plea made most simply and expressively by the writers of the letter. From the Europe-North American axis it is very easy conveniently to forget the difficulties of doing science elsewhere, to look down on scientists struggling with poor facilities and heavy teaching loads, and to ignore colleagues off the axis when passing round the gossip, the early warnings, the bits of advice. Even well endowed Australians, with regular jet flights to the Northern Hemisphere, know that. How much more so does the problem afflict Argentinians, and how much more must we simply not stand by uninterested. 